\title{
Small innovation enterprises: Russian data
}

\section{МАЛЫЕ ИННОВАЦИОННЫЕ ПРЕДПРИЯТИЯ: ДАННЫЕ РОССИИ}

Received: April 4, 2021

\begin{abstract}
Increasing the innovation activity of small enterprises is an urgent problem in Russia and its regions. Innovations include both the production of new or improved products (goods and services) that are significantly different from previously produced products, and the introduction of new or more advanced production processes in enterprises that are significantly different from those that were previously used. The aim of the study was to assess the levels of innovation use based on the specific weight of small innovative enterprises in the total number of small enterprises in the regions of Russia. The study used mathematical modeling of empirical data for all regions and the construction of the corresponding density functions of the normal distribution. The official information of the Federal State Statistics Service for 2015, 2017 and 2019 was considered as the initial empirical data. The study included the study of indicators that characterize the share of small innovative enterprises. The average values of the indicators were determined, as well as the ranges of their changes in the regions of Russia. The conclusions of the study, which contain scientific novelty and originality, are as follows: it is proposed to use economic and mathematical models to evaluate the values of indicators that characterize the innovation activity of small enterprises; it is shown that almost every twentieth small enterprise in Russia showed a certain innovation activity during the period under review; it is shown that the values of the specific weights of small innovative enterprises in the total number of small enterprises were significantly
\end{abstract}

Accepted: May 9, 2021

Written by:

I.S. Pinkovetskaia ${ }^{17}$ https://orcid.org/0000-0002-8224-9031

N.V. Schennikova ${ }^{18}$

https://orcid.org/0000-0001-8192-5862

L.I. Kryukova ${ }^{19}$

https://orcid.org/0000-0002-7465-3798

Y.V. Sadchikova ${ }^{20}$

https://orcid.org/0000-0003-4637-3614

L.A. Sudovchikhina ${ }^{21}$

https://orcid.org/0000-0003-4086-7605

\footnotetext{
${ }^{17}$ Economic analysis and State Management Department, Ulyanovsk State University, Ulyanovsk, Russia.

${ }^{18}$ Translation and Translation Studies Department, Penza State University, Penza, Russia.

${ }^{19}$ Translation and Translation Studies Department, Penza State University, Penza, Russia.

${ }^{20}$ Translation and Translation Studies Department, Penza State University, Penza, Russia.

${ }^{21}$ Translation and Translation Studies Department, Penza State University, Penza, Russia.
} 


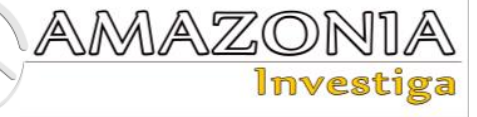

differentiated by region; the regions with the maximum and minimum values of the specific weights of small innovative enterprises are identified.

Keywords: innovations, small innovative enterprises, regions of Russia, functions of normal distribution, assessment of the use of innovations.

каждое двадцатое малое предприятие в России проявляло за рассматриваемый период определенную инновационную активность; показано, что значения удельных весов малых инновационных предприятий в общей численности малых предприятий были существенно дифференцированы по регионам; выявлены регионы с максимальными и минимальными значениями удельных весов малых инновационных предприятий.

Ключевые слова: инновации, малые инновационные предприятия, регионы России, функции нормального распределения, оценка использования инноваций.

\section{Introduction}

Small businesses are constantly faced with the problems of selling manufactured goods and services due to the growing demands of customers, the need to ensure competitiveness in the markets, and the desire to improve the efficiency of their activities.

To solve these problems, enterprises need to improve and update their products; modernize with new equipment and tools; develop specialization; use better raw materials and components; introduce advanced technological processes; improve the functions and management methods performed; improve the competencies of employees; improve logistics and marketing strategies; improve the environmental friendliness of their production (Mompo \& Redoli, 2009; Gunday et al., 2011; Slack et al., 2015).

It should be noted that previously, innovative activity was described in research as scientific, research, industrial or technological activity. At present, this innovative activity combines a comprehensive, holistic system of activities carried out at enterprises in order to increase their efficiency (Putera \& Jannah, 2012). Significantly, in addition to economic goals, it seeks to address issues of increasing employee income, firm sustainability, and improving socialization (Geels, 2004).

It is important for innovation activities to take into account the characteristics of enterprises specializing in various types of economic activities (Mazzucato \& Penna, 2016). This approach should take into account the exchange of technology between different industries and increase macroeconomic stability by stimulating firm activity (Hausman \& Rodrik, 2003). It should be noted that innovation should extend not only to high-tech activities (for example,

manufacturing), but also to all sectors of national economies (Martin, 2013), including trade, services (Benaim \& Tether, 2016), as well as social activities (Van der Have \& Rubalcaba, 2016).

When implementing innovations, it is necessary to take into account five main elements (Fagerberg, 2017):

- $\quad$ knowledge that is formed by state research organizations and universities, as well as supplemented by their own developments of various firms;

- $\quad$ skills, both highly specialized and general, that are formed in educational processes, including professional training of people;

- availability of demand for innovative solutions by creating appropriate markets, as well as using public procurement;

- state financing of innovative initiatives of small enterprises and individual entrepreneurs, as well as reducing the tax burden on these categories of actors;

- improving the institutional support of economic processes based on the promotion of innovation in legislative and regulatory acts, based on the needs of the business community.

In recent years, small business in Russia has generated significant economic growth, an increase in gross domestic product, the creation of new jobs and the reduction of poverty (Kiseleva et al., 2019; Pinkovetskaia et al., 2019; Pinkovetskaia et al., 2020a; Pinkovetskaia et al., 2020b). Russia has formed high expectations for the growth of innovation in the economy. Based on the introduction of innovations, it is planned to move to more technological and efficient forms and methods of enterprise activity, including small enterprises. In Russia, 
innovation activity is currently defined by the provisions set out in Presidential Decree (Presidential Decree No. 204, 2018). This document provides for an increase in the number of organizations that have implemented technological innovations to fifty percent of their total number. The problem of increasing innovation activity is relevant in modern conditions. At the same time, it seems logical to develop innovations in all regions of Russia.

\section{Literature review}

Scientific research examines innovations related to changes in existing knowledge, technological processes, the use of new technology and other opportunities and resources in various types of economic activities (Fagerberg et al., 2010), including low-tech and high-tech (Tunzelmann \& Acha, 2004), in the service sector (Rubalcaba et al., 2012).

Table 1.

Scientific publications on innovation in Russia.
In recent years, the study of the characteristics of innovative enterprises has become particularly relevant and has included the analysis of factors that affect their effectiveness (Liu \& White, 2001; Smits \& Kuhlmann, 2004). Since 1991, the countries of the European Union have been collecting information describing not only the innovation activities of firms, but also the factors influencing them (Smith, 2004). It should be noted that the processes of mutual influence of the elements of national innovation systems in most cases are stable, despite the changes occurring in the regions (Pierson, 2000).

A number of scientific publications are devoted to the problem of innovation activity in Russia. Let's look at the most interesting of them, which were published in 2019-2020. A brief description of these publications is given in table 1 .

\begin{tabular}{|c|c|c|c|c|}
\hline Authors & Studied questions & $\begin{array}{l}\text { Period, } \\
\text { years }\end{array}$ & $\begin{array}{l}\text { Objects of } \\
\text { innovation }\end{array}$ & $\begin{array}{l}\text { Type of } \\
\text { indicators }\end{array}$ \\
\hline 1 & 2 & 3 & 4 & 5 \\
\hline Petrikov (2019) & $\begin{array}{l}\text { Analysis of the directions of innovation } \\
\text { activity, priority for individual regions }\end{array}$ & 2016-2017 & $\begin{array}{l}\text { Regions of the } \\
\text { Central Federal } \\
\text { District }\end{array}$ & indices \\
\hline $\begin{array}{l}\text { Podsolonko et } \\
\text { al. (2019) }\end{array}$ & $\begin{array}{l}\text { Analysis of the transfer of innovative } \\
\text { technologies by type of economic } \\
\text { activity }\end{array}$ & $2010-2016$ & Russia & indices \\
\hline $\begin{array}{l}\text { Arkhipova et al. } \\
\text { (2019) }\end{array}$ & $\begin{array}{l}\text { Assessment of the volume of innovative } \\
\text { goods produced and services rendered } \\
\text { and work performed by small } \\
\text { businesses }\end{array}$ & 2016 & Russian regions & absolute \\
\hline $\begin{array}{l}\text { Zhuravlev } \\
(2020)\end{array}$ & $\begin{array}{l}\text { Assessment of the degree of readiness } \\
\text { of the regional economic complex for } \\
\text { innovation based on regression analysis }\end{array}$ & $2007-2017$ & $\begin{array}{l}\text { Regions of the } \\
\text { Central and North- } \\
\text { Western Federal } \\
\text { Districts }\end{array}$ & absolute \\
\hline $\begin{array}{l}\text { Belemaeva \& } \\
\text { Kalimullin } \\
(2020)\end{array}$ & $\begin{array}{l}\text { Increase in the market capitalization of } \\
\text { a company that regularly innovated }\end{array}$ & 2001-2012 & One company & absolute \\
\hline $\begin{array}{l}\text { Deputatova \& } \\
\text { Perelman }(2020)\end{array}$ & $\begin{array}{l}\text { Analysis of innovative technologies and } \\
\text { methods for attracting buyers }\end{array}$ & $2015-2018$ & $\begin{array}{l}\text { Trade sector in } \\
\text { Russia }\end{array}$ & absolute \\
\hline Yezhov (2020) & $\begin{array}{l}\text { Dynamics of changes in innovative } \\
\text { activity of enterprises. Business } \\
\text { participation in scientific developments. } \\
\text { Barriers to innovation }\end{array}$ & 2014-2018 & Russia & $\begin{array}{l}\text { absolute, } \\
\text { specific }\end{array}$ \\
\hline $\begin{array}{l}\text { Kudryavtseva } \\
(2020)\end{array}$ & $\begin{array}{l}\text { Institutional aspects of state } \\
\text { support for innovations in production } \\
\text { technologies }\end{array}$ & $2012-2015$ & Countries & indices \\
\hline $\begin{array}{l}\text { Lipovka \& } \\
\text { Arnautova } \\
(2020)\end{array}$ & $\begin{array}{l}\text { Innovative development based on } \\
\text { information technologies }\end{array}$ & $2015-2018$ & Gypermarket & absolute \\
\hline Smirnova (2020) & $\begin{array}{l}\text { Dynamics of changes in the share of } \\
\text { innovative enterprises. Factors that } \\
\text { reduce the effectiveness of innovation } \\
\text { implementation }\end{array}$ & $2000-2014$ & Russia & specific \\
\hline
\end{tabular}

Source: Achieved by the authors 


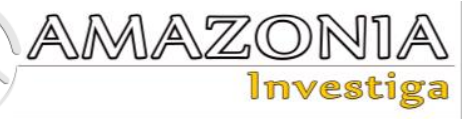

Based on the information given in Table 1, it can be stated that the problem of studying regional innovation activity is relevant in Russia. At the same time, in theoretical and applied research to date, unjustifiably little attention has been paid to the comparative analysis of the activities of small enterprises that carried out technological innovations in the regions of Russia. In the same works where such an analysis was available, the absolute values of innovation activity were compared, as a rule, which is not always logical, since regions differ significantly in the number of economic entities, population, size and location.

\section{Methodology and design}

The purpose of our study was to assess the levels of innovation use based on the share of small innovative enterprises in the total number of small enterprises operating in the regions of Russia.

To date, the main aspects of innovation activities of organizations are presented in detail in the document (OECD, 2018). At the same time, innovations are understood as the production of new or improved products (goods and services) that differ significantly from previously produced products, as well as the introduction of new or more advanced production processes in enterprises that differ significantly from those that were previously used. Accordingly, innovations can be of two types. The first type of innovation involves better products and services, and the second type is associated with changes in production processes. Both of these types of innovations are united by such a concept as technological innovation. It should be noted that innovations aimed at creating new or improving existing production processes, in turn, are divided into the following subspecies:

- changes in production technologies and the creation of new products (goods and services) in various industries;

- changes in logistics, transport, and distribution operations related to the supply of organizations and the sale of finished products;

- improving the technology and organization of information processes;

- $\quad$ use of more effective methods of conducting and managing production activities, including accounting and control issues;

- development of interaction of organizations with the external environment;

- improving the effectiveness of personnel policy;
- improvement of methods and forms of marketing and pricing.

An analysis of previous studies, including those presented in Table 1, has led to the conclusion that it is advisable to use the share of innovative small enterprises in the total number of such enterprises in each of the regions of Russia as an indicator of the level of innovation activity in the regions.

The research process included three stages. At the first stage, the initial empirical data describing the share of innovative small enterprises in the total number of small enterprises operating in the regions of Russia were formed. At the second stage, the distribution of specific innovation values across the country's regions was evaluated. At the third stage, a comparative analysis was carried out, during which the regions of the country were established, in which the minimum and maximum values of specific innovations were noted.

As initial information, the study used official statistics for 2015-2019 on the share of innovative organizations in the total number of organizations in 82 regions of Russia (Federal State Statistics Service, 2021).

In the economic and mathematical modeling used to estimate the distribution of specific innovation values across the country's regions, the normal distribution function was used. The author's paper (Pinkovetskaia \& Slepova, 2018) present a methodological approach to the development and use of such a function to determine the average value of the indicator for the considered regions, as well as the range of its variation.

The study included testing the following three hypotheses:

- hypothesis 1 - average values of indicators characterizing the share of Russian small enterprises that implemented technological innovations did not change significantly over the period from 2017 to 2019 ;

- hypothesis 2 - values of the share of innovative small enterprises in their total number have a significant differentiation across different regions;

- $\quad$ hypothesis 3 - territorial location of regions does not significantly affect the share of innovative small enterprises. 


\section{Results of research}

In the course of the computational experiment, economic and mathematical modeling was carried out on the basis of empirical data. The models that describe the distribution of the three indicators for different years across 82 regions of Russia are shown below:

- the share of innovative small enterprises in the total number of small enterprises by region in $2015, \%$

$$
y_{1}\left(x_{1}\right)=\frac{206.29}{3.01 \times \sqrt{2 \pi}} \cdot e^{-\frac{\left(x_{1}-4.54\right)^{2}}{2 \times 3.01 \times 3.01}}
$$

- the share of innovative small enterprises in the total number of small enterprises by region in $2017, \%$

$$
y_{2}\left(x_{2}\right)=\frac{206.28}{2.69 \times \sqrt{2 \pi}} \cdot e^{\frac{-\left(x_{2}-4.88\right)^{2}}{2 \times 2.69 \times 2.69}}
$$

Table 2.

Values of indicators of the share of innovative small enterprises, $\%$

\begin{tabular}{llc}
\hline Indicator & Average values & $\begin{array}{c}\text { Values for most } \\
\text { regions }\end{array}$ \\
\hline 1 & 2 & 3 \\
$\begin{array}{l}\text { share of innovative small enterprises in the total number of small } \\
\text { enterprises by region in 2015 } \\
\text { share of innovative small enterprises in the total number of small } \\
\text { enterprises by region in 2017 } \\
\begin{array}{l}\text { share of innovative small enterprises in the total number of small } \\
\text { enterprises by region in 2019 }\end{array}\end{array}$ & 4.54 & $1.53-7.55$ \\
\hline
\end{tabular}

Source: The calculations are carried out by the author on the basis of functions (1)-(3).

The data shown in Table 2 show that the average values of the share of innovative small enterprises in the total number of small enterprises operating in the regions were in the range from $4.54 \%$ to $5.50 \%$ in $2015-2019$. That is, on average, in the regions under consideration, only one in twenty small enterprises participated in innovation activities. It should be noted that during this period, no significant changes were observed, both in the average values and in the values typical for most regions. The first hypothesis was confirmed.

To test hypothesis 2 on the differentiation of indicators by region, the analysis of the range of variation of each of the indicators presented in Table 2 was carried out. The coefficients of variation (the ratio of the mean square deviations
- the share of innovative small enterprises in the total number of small enterprises by region in $2019, \%$

$$
y_{3}\left(x_{3}\right)=\frac{152.09}{2.77 \times \sqrt{2 \pi}} \cdot e^{-\frac{\left(x_{3}-5.50\right)^{2}}{2 \times 2.77 \times 2.77}}
$$

The high quality of functions (1)-(3) was confirmed in the testing process according to the Shapiro-Wilk, Pearson, and KolmogorovSmirnov criteria.

\section{Discussion}

At the next stage of the study, patterns were identified that characterize the distribution of the considered indicators. Column 2 (Table 2) shows the data describing the average values of the indicators. The ranges in which the values of the indicators for most countries are shown in the third column of the table. to the average values of the indicators) were: for the first indicator $-66 \%$, for the second indicator $-55 \%$, for the third indicator $-50 \%$. Thus, the analysis showed a significant differentiation in the considered regions of the values of each of the three indicators. Therefore, hypothesis 2 was confirmed.

At the next stage, the regions where the maximum and minimum values of each of the indicators were noted in 2019 were identified. At the same time, the maximum and minimum values are those that correspondingly exceed the upper limits of the ranges shown in the third column of Table 2 and are smaller than the lower limits of the ranges. The results of this analysis are shown in Table 3. Along with the lists of regions, this table also shows the division of the 


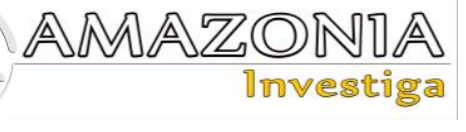

identified regions by their geographical location and the specific weights of small innovative

Table 3.

Regions with maximum and minimum values of indicators.

\begin{tabular}{|c|c|c|}
\hline Indicator & Maximum values & Minimum values \\
\hline 1 & 2 & 3 \\
\hline $\begin{array}{l}\text { the share of small } \\
\text { innovative } \\
\text { enterprises in the } \\
\text { total number of small } \\
\text { enterprises by region } \\
\text { in } 2019\end{array}$ & $\begin{array}{l}\text { Kurgan area }(8.5 \%) \text {, Voronezh area } \\
(8.67 \%) \text {, Krasnoyarsk territory }(8.86 \%) \text {, } \\
\text { Penza area }(8.87 \%) \text {, Vologda area }(9.03 \%) \text {, } \\
\text { Republic of Mari El }(9.35 \%) \text {, Republic of } \\
\text { Crimea }(9.4 \%) \text {, Udmurtia }(9.69 \%) \text {, } \\
\text { Republic of Mordovia }(10.17 \%) \text {, Oryol area } \\
(10.2 \%), \text { Belgorod area }(10.53 \%) \text {, Moscow } \\
\text { city }(11.03 \%), \text { Lipetsk area }(13.04 \%) \text {, Altai } \\
\text { territory }(13.2 \%) \text {. } \\
\text { Located in the Central (five regions), } \\
\text { North-West (one region), the Volga (four } \\
\text { regions), southern (single region), Siberian } \\
\text { (two regions) Federal districts. }\end{array}$ & $\begin{array}{l}\text { Sakhalin area }(0.96 \%) \text {, Republic of } \\
\text { Adygea }(1.41 \%) \text {, Kaliningrad area } \\
(1.57 \%) \text {, Republic of Karelia }(1.59 \%) \text {, } \\
\text { Republic of North Ossetia }(1.82 \%) \text {, } \\
\text { Zabaikal territory }(2.08 \%) \text {, } \\
\text { Stavropol territory }(2.18 \%) \text {, Amur area } \\
(2.27 \%) \text {, Tyumen area }(2.52 \%) \text {, Tver area } \\
(2.65 \%) \text {. } \\
\text { They are located in the Northwestern (two } \\
\text { regions), Central (one region), North } \\
\text { Caucasus (three regions), Siberian (three } \\
\text { regions), Ural (one region), and Far } \\
\text { Eastern (three regions) federal districts. }\end{array}$ \\
\hline
\end{tabular}

Source: Developed by the author on the basis of data from Table 1 and official statistical information.

Table 3 provides information on the territorial location of the regions with the maximum (column 2) and minimum (column 3) values of the share of small innovative enterprises in 2019. The analysis of this information showed that there was no correlation between the values of the indicators for the regions and their territorial location. Thus, we can state the confirmation of the third hypothesis.

It should be noted that even the regions with the largest share of small innovative enterprises (the city of Moscow, the Lipetsk region and the Altai Territory) have not yet reached the level defined in the Presidential Decree (Presidential Decree No. 204, 2018).

\section{Conclusions}

The purpose of the study, which was to assess the levels of innovation use based on taking into account the share of small innovative enterprises in the total number of small enterprises in the regions of Russia for 2015, 2017 and 2019, was achieved. The conclusions that have scientific novelty and originality include:

1. The article presents a methodology for assessing the share of small innovative enterprises in the total number of small enterprises in the regions of Russia.

2. Modeling of the distribution of indicators based on data for 2015, 2017, and 2019 was carried out.

3. It is proved that the values of the share of small innovative enterprises in the total number of small enterprises have not changed significantly over the years considered.

4. It is shown that almost every twentieth small enterprise in Russia showed a certain innovative activity during the period under review.

5. It is shown that the values of the specific weights of small innovative enterprises in the total number of small enterprises were significantly differentiated by region.

6. The regions with the maximum and minimum values of the specific weights of small innovative enterprises in the total number of small enterprises are identified.

7. It is proved that there is no influence of the territorial location of the regions on the minimum and maximum values of the considered indicators.

The results of our work have a certain theoretical and practical significance. The methodological approach presented in the article to estimate the share of small innovative enterprises in the total number of small enterprises in the regions of Russia can be used in further research. Namely, when monitoring the share of innovative small enterprises in the regions and municipalities of Russia. The results of the work can be applied in the current activities of state structures and public organizations, when justifying measures to support innovation activities in accordance to Presidential Decree (2018). In addition, the information obtained can be used to solve problems of increasing the share of innovative small enterprises in regions where such 
enterprises are not widely developed. The results of the work are of interest to leasing companies that ensure the introduction of new equipment and advanced technologies. The new knowledge gained is of interest and can be used in the educational process at universities.

Further research can be carried out to assess the industry characteristics characteristic of innovative small enterprises.

In the course of the study, there were no restrictions on empirical data, since information was considered for all 82 regions of Russia.

\section{References}

Arkhipova, M., Sirotin, V., \& Afonina, V. (2019). Modeling of innovative activity of small and medium-sized businesses. Intelligence. Innovation. Investment, 5, 20-30.

Belemaeva, A., \& Kalimullin, D. (2020). Analysis of the significance of innovation assessment in the process of increasing the capitalization of an enterprise. Economics and Business: theory and practice, 1-1(59). 35-38.

Benaim, M., \& Tether, B. (2016). Innovation Policies for a Creative Economy. Challenging the Dominance of STI and Research. Presented at the EU-SPRI Conference. Lund. Sweden. 8-10 June. https://scholar.google.com/scholar?hl=en\&as_s $\mathrm{dt}=0,5 \&$ cluster $=14593146814109751730$

Deputatova, E., \& Perelman, M. (2020). Aspects of studying consumer behavior in the context of innovations in retail. Economics and Business: theory and practice, 1-1 i(59). 101-104.

Federal State Statistics Service. (2021). Science and innovation. URL: https://rosstat.gov.ru/folder/14477?print=1.

(accessed: 15.01.2021).

Fagerberg, J. (2017). Innovation policy: Rationales, lessons and challenges. Journal of Economic Surveys, April. 1-20.

Fagerberg, J., Srholec, M., \& Verspagen, B. (2010). The Role of Innovation in Development. Review of Economics and Institutions, 1(2). 1-29.

Geels, F.W. (2004). From sectoral systems of innovation to socio-technical systems: Insights about dynamics and change from sociology and institutional theory. Research policy, 33(6-7). 897-920.

Gunday, G., Ulusoy, G., Kilic, K., \& Alpkan, L. (2011). Effects of innovation types on firm performance. International Journal of Production Economics, 133(2), 662-676.

Hausman, R., \& Rodrik, D. (2003). Economic development as self-discovery. Journal of Development Economics, 72(2), 603-633.
Kiseleva, O., Lebedev, A., Pinkovetskaia, I., Rojas-Bahamón, M., \& Arbeláez-Campillo, D. (2019). Specialization and concentration of small and medium enterprises employees: Russian data. Amazonia Investiga, 8(20), 6-15. https://amazoniainvestiga.info/index.php/amazo nia/article/view/59

Kudryavtseva, S. (2020). Technological readiness of industry for open innovations. Economics in industry, 13(1), 48-58.

Lipovka, N., \& Arnautova, E. (2020). Influence of innovations on the enterprise economy. Actual problems and prospects of economic development: Russian and foreign experience, 1(26), 46-49.

https://elibrary.ru/item.asp?id=42387035

Liu, X., \& White, S. (2001). Comparing innovation systems: a framework and application to China's transitional context. Research Policy, 30, 1091-1114.

Martin, B.R. (2013). Innovation Studies: An Emerging Agenda. J. Fagerberg, B.R. Martin, E.S. Andersen (eds). Innovation Studies: Evolution and Future Challenges. Oxford: Oxford University Press, 168-186.

Mazzucato, M., \& Penna, C.C. (2016). Beyond market failures: the market creating and shaping roles of state investment banks. Journal of Economic Policy Reform, 19(4), 305-326.

Mompo, R., \& Redoli, J. (2009). Innovation strategies for small and medium-sized enterprises. Innovation, 9(1), 57-59.

OECD. (2018). Eurostat. Oslo Manual 2018: Guidelines for Collecting, Reporting and Using Data on Innovation, 4th Edition, The Measurement of Scientific, Technological and Innovation Activities. Luxembourg: OECD Publishing, Paris/Eurostat. 258 p. https://www.oecd.org/science/oslo-manual2018-9789264304604-en.html

Petrikov, A. (2019). Features of innovative development of the regions of the Central Federal District of the Russian Federation. The economy of sustainable development, 1(37), 64-66.

Pierson, P. (2000). Increasing Returns, Path Dependence, and the Study of Politics. The American Political Science Review, 94, 251-267. Pinkovetskaia, I.S., Kostina, T.I., \& Berezina, N.V. (2020a). Evaluation of indicators of entrepreneurial potential in 2018. Amazonia Investiga, $\quad 9(27), \quad$ 173-179. https://amazoniainvestiga.info/index.php/amazo nia/article/view/1225

Pinkovetskaia, I., Lyubovtseva, E., Arbeláez-Campillo, D., \& Rojas-Bahamón, M. (2020b). Small and medium enterprises in Russia and other countries. Amazonia Investiga, 9(25), 99-106. 


\section{AMA}

https://amazoniainvestiga.info/index.php/amazo nia/article/view/1034

Pinkovetskaia, I., Nuretdinova, Y., Treskova, T., $\&$ Neif, N. (2019). Estimation of fixed capital investment in Russian small enterprises and microenterprises in 2018. Amazonia Investiga, $8(21)$, 42-51. https://amazoniainvestiga.info/index.php/amazo nia/article/view/46

Pinkovetskaia, I., \& Slepova, V. (2018). Estimation of Fixed Capital Investment in SMEs: the Existing Differentiation in the Russian Federation. Business Systems Research, 9(1), 65-78.

Podsolonko, V., Podsolonko, E., \& Slepokurov, A. (2019). Management of innovations and technology transfer for improving the efficiency of the economy. Scientific Bulletin: finance, banks, investments, 2(47), 136-151. https://elibrary.ru/item.asp?id=41324800

Presidential Decree No. 204. On National Goals and Strategic Objectives for the Development of the Russian Federation for the period up to 2024, of May 7, 2018. http://www.kremlin.ru/acts/bank/43027/print Putera, P., \& Jannah, L. (2012). Science \& Technology and Innovation Policies in Science \& Technological Research, Development, and Implementation. International Journal of Administrative Science \& Organization, 19(3), 206-215

https://www.researchgate.net/publication/25948 3776_Science_Technology_and_Innovation_Po licies_in_Science_Technological_Research_De velopment_and_Implementation

Rubalcaba, L., Michel, S., Sundbo, J., Brown, S.W., \& Reynoso, J. (2012). Shaping,
Organizing, and Rethinking Service Innovation: A Multidimensional Framework. Journal of Service Management, 23(5), 696-715.

Slack, N., Brandon-Jones, A., \& Jhonston, R. (2015). Administração da Produção (4 ed.). São Paulo: Atlas.

Smirnova, A. (2020). Innovations as the main tool for improving the competitiveness of Russian business structures. Science-practical research, 1-3(24), 237-243.

Smith, K. (2004). Measuring Innovation. in Fagerberg, J., Mowery, D., Nelson, R. (eds.). The Oxford Handbook of Innovation. Oxford: Oxford University Press, 148-178.

Smits, R., \& Kuhlmann, S. (2004). The rise of systemic instruments in innovation policy. International Journal of Foresight and Innovation Policy, 1, 4-32.

Tunzelmann, N., \& Acha, V. (2004). Innovation in "Low-tech" Industries. in J. Fagerberg, D. Mowery, R. Nelson (eds). The Oxford Handbook of Innovation. Oxford: Oxford University Press, 407-432.

Van der Have, R. P., \& Rubalcaba, L. (2016). Social Innovation Research: An Emerging Area of Innovation Studies? Research Policy, 45(9), 1923-1935.

Yezhov, A. (2020). Modern problems of implementation and management of innovations in the Russian Federation. Innovations and investments, 2, 12-14.

Zhuravlev, D. (2020). Assessment of the technological readiness of the regional economy for the perception of innovations. Economic revival of Russia, 1(63), 138-147. 